\title{
Gastric Diffuse Large B-Cell Lymphoma
}

National Cancer Institute

\section{Source}

National Cancer Institute. Gastric Diffuse Large B-Cell Lymphoma. NCI Thesaurus. Code C5253.

An extranodal diffuse large B-cell lymphoma that arises from the stomach with the bulk of the mass located in the stomach. 